\title{
A review of Dendrocephalus (Dendrocephalinus) (Crustacea: Anostraca) with the first records of male-male anostracan aggressive competition
}

\author{
D. Christopher ROGERS ${ }^{1, *}$, Ann DUNN ${ }^{2} \&$ W. Wayne PRICE ${ }^{3}$ \\ ${ }^{1}$ Kansas Biological Survey, Kansas University, Higuchi Hall, 2101 Constant Avenue, \\ Lawrence, KS 66047-3759, USA. \\ ${ }^{2} 14391$ Campbell Farm Lane, Lovettsville, VA 20180, USA. \\ ${ }^{3}$ Department of Biology, University of Tampa, Tampa, Florida, USA. \\ ${ }^{*}$ Corresponding author: Branchiopod@gmail.com \\ ${ }^{2}$ Email: ard224@cornell.edu \\ ${ }^{3}$ Email: wprice@ut.edu \\ ${ }^{1}$ urn:lsid:zoobank.org:author:77D95892-8588-4016-88A9-73A2A1E1815F \\ ${ }^{2}$ urn:lsid:zoobank.org:author:3F2619C0-CDF7-40D5-AAEC-61190C976889 \\ ${ }^{3}$ urn:1sid:zoobank.org:author:
}

\begin{abstract}
We present a review of Dendrocephalus (Dendrocephalinus) with an updated diagnosis for the subgenus and a key to all known species. We provide new records of Dendrocephalus alachua, which was previously supposed to be extinct, and we describe a new species, Dendrocephalus proeliator sp. nov., which is separated from all other species based on the form of the male frontal appendage. Dendrocephalus proeliator sp. nov. appears to be morphologically intermediate between $D$. alachua and $D$. lithaca. In addition, we provide conservation assessments for all four species in the subgenus, according to IUCN Red List standards. We also report for two species the first known examples of direct male-male agonistic behaviour and competition for access to areas frequented by receptive females.
\end{abstract}

Keywords. Fairy Shrimp, Florida, hill topping, sexual selection, new species.

Rogers D.C., Dunn A. \& Price W.W. 2019. A review of Dendrocephalus (Dendrocephalinus) (Crustacea: Anostraca) with the first records of male-male anostracan aggressive competition. European Journal of Taxonomy 509: 1-14. https://doi.org/10.5852/ejt.2019.509

\section{Introduction}

Dendrocephalus Daday, 1908 is a new world genus in the Thamnocephalidae, with two subgenera (Rogers 2006). Dendrocephalus s. str. ranges from Argentina, north through to Costa Rica, the Galápagos Islands, and Aruba, with 17 described species (Brendonck et al. 1990; Belk et al. 2002; Rogers 2013; Rogers et al. 2012; Rogers \& Volcan 2016; Rabet et al. 2018). Rogers \& Volcan (2016) provided keys to the species of this subgenus, and improved keys are in development (Rogers et al., in press). 
The subgenus Dendrocephalinus is limited to the extreme southern United States of America (Georgia, Florida, and Texas), and has three described species (Rogers 2006, 2013). We review the subgenus, provide an updated key to the species, and discuss the conservation status of each. We present a new species of Dendrocephalinus from Florida and describe its remarkable male-male territorial aggressive behaviour.

\section{Material and methods}

Material was examined in museum collections or collected live from the wild, and cultured using the wild collections. Material of the new species was examined from the Florida Museum of Natural History, sent to the first author for identification. All preserved material was examined under a Wild M8 stereo dissection microscope. All drawings are freehand. Live adult specimens were collected using a dip net from the water column. The specimens are preserved in $70 \%$ ethyl alcohol, which was changed after 24 hours. Substrate from one of the localities was collected together with live eggs of the new species.

Frontal appendage terminology follows Pereira (1983). Conservation assessments follow the guidelines produced by the IUCN (2001).

Cultures were started using techniques that simulate natural seasonal temperature and hydrologic cycles of the original collection habitat. A 11 portion of the substrate was gently deposited in a plastic culture container $(58 \mathrm{~cm} \times 41 \mathrm{~cm} \times 16 \mathrm{~cm})$, and lightly sprayed with deionized water to prevent dust or debris and eggs from being displaced into the air during inundation. The substrate was initially inundated by adding 161 of deionized water that had been warmed to $25^{\circ} \mathrm{C}$. The culture was then gently stirred to break up substrate clumps, and gentle aeration via an air stone was added at one corner of the container. The culture was incubated at $25^{\circ} \mathrm{C}$ for 12 hours, then let come to room temperature. After $24 \mathrm{~h}$, a second 161 of $25^{\circ} \mathrm{C}$ deionized water was added to the culture container. The culture was maintained at room temperature under T12 fluorescent grow lights on a timed 12:12-h light:dark cycle. Cultures were fed $5 \mathrm{ml}$ to $10 \mathrm{ml}$ of a diet high calcium plant flake food (WorldWide Aquatics, Inc.) ground to a fine powder. In addition, $48 \mathrm{~h}$ after the second addition of water, $20 \mathrm{ml}$ of a free swimming green alga culture (Selenastrum sp.) was added for additional food.

\section{Repositories}

$\mathrm{DCR}=$ author's own collection

FLMNH $=$ Florida Museum of Natural History, Florida, USA

USNM = National Museum of Natural History, Washington, D.C., USA

\section{Results}

Subphylum Crustacea Brünnich, 1772

Class Branchiopoda Latreille, 1817

Order Anostraca Sars, 1867

Family Thamnocephalidae Packard, 1883 (sensu Rogers 2006)

Genus Dendrocephalus Daday, 1908 (sensu Rogers 2006)

Subgenus Dendrocephalinus Rogers, 2006

Dendrocephalinus Rogers, 2006: 7, 12, fig. 1D.

Chirocephalus - Creaser 1940: 435, figs 1-6. 
Branchinella - Dexter 1953: 756, 761, figs 24-28. - Moore 1967: 219, figs 1-3. - Belk \& Sissom 1992: 312, figs 1-3. — Belk \& Brtek 1995: 323, 325. — Brendonck 1997: 451-454. — Brtek \& Mura 2000: 1077, figs 12-17. — Brtek 1997: 21-22. — Brtek 2002: 54.

\section{Type species}

Chirocephalus lithacus Creaser, 1940 (by designation herein)

Diagnosis (Updated from Rogers 2006)

Fully extended gonopods extending to third or base of fourth abdominal segment. Gonopod basal portion chitinised, rigid, subcylindrical, bearing a single ventromedial tubercle. Gonopod distal eversible portion soft, distal third expanded, comb plate lacking, distal half with four longitudinal rows of short spines, each row evenly spaced around gonopod. Brood pouch expanded proximally, distal portion either narrowing abruptly to posteriorly directed subcylindrical tube, extending to base of fourth to eighth abdominal segment, or absent. Male abdomen first two or three segments with ventrolateral spiniform projections. Male first thoracopods unmodified. Nearctic (USA, Mexico (?)). All species occur within the Coastal Plain anostracan biogeographic region (Rogers, 2014a).

\section{Remarks}

We suspect that this taxon may actually represent an independent genus, however molecular analyses will be required to demonstrate this. At this time we choose to conservatively maintain the taxon as a subgenus.

Dendrocephalus (Dendrocephalinus) acacioidea (Belk \& Sissom, 1992)

Fig. 1A, D

Branchinella acacioidea Belk \& Sissom, 1992: 312, figs. 1-3.

Branchinella acacioidea - Belk \& Brtek 1995: 323. — Brendonck 1997: 451, 454. — Brtek 1997: 21; 2002: 54.

Dendrocephalus (Dendrocephalinus) acacioidea - Rogers 2006: 7, 12, fig. 1D.

\section{Material examined}

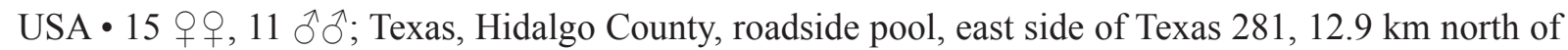
Edenberg; $26^{\circ} 25^{\prime}$ N, 98³0’ W; 21 Aug. 1980; S.L. Sissom leg.; gift from D. Belk; DCR \#321.

\section{Remarks}

This species is unique in that the 2A sub-branch (the apical branch) is absent, and sub-branch $2 \mathrm{~V}$ and $1 \mathrm{D}$ are identical. The female shares the elongated brood pouch form with D. proeliator sp. nov. The only member of the subgenus occurring outside the extreme southeastern USA: all records are from southern, coastal Texas. All known locality substrates have $10-15 \%$ calcium carbonate and $2-8 \mathrm{mS} / \mathrm{cm}$ salinity (Rogers 2014b).

So far, this species is known from three nearby locations, all seem to be on either private land or in public right of ways (Belk \& Sissom 1992). Due to the limited distribution of D. acacioidea, this species meets the IUCN red list CR B1a,b species criteria (IUCN 2000), which means the species is Critically Endangered, with an extent of occupancy less than $100 \mathrm{~km}^{2}$, and a projected decline in extent of occurrence. 

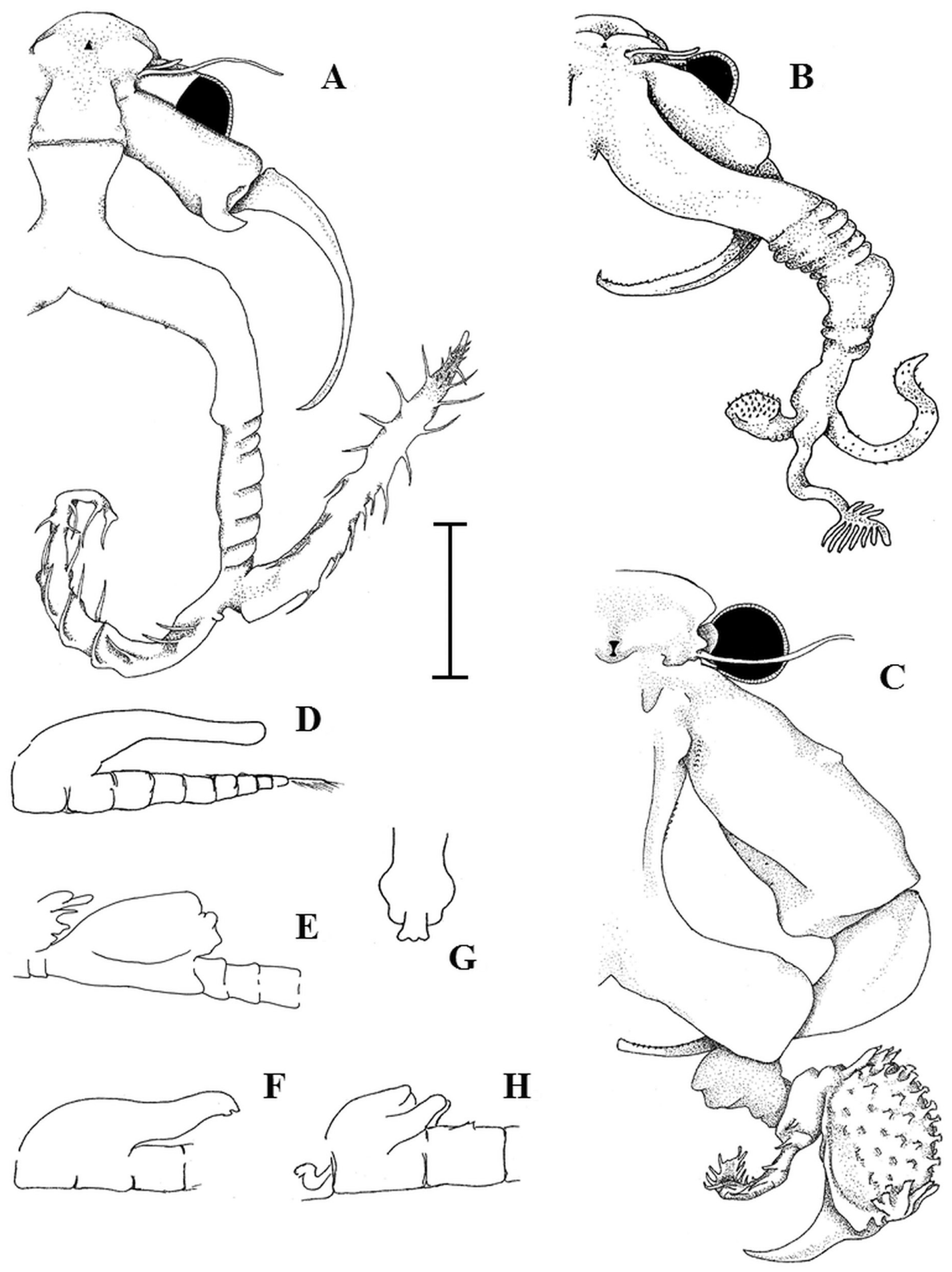

Fig. 1. Dendrocephalus spec. A. Dendrocephalus acacioidea, male head, left side, anterior view. B. Dendrocephalus alachua, male head, left side, anterior view. C. Dendrocephalus lithacus, male head, left side, anterior view. D. Dendrocephalus acacioidea, brood pouch, right, lateral view. E. Dendrocephalus alachua, brood pouch, right, lateral view. F. Dendrocephalus lithacus, brood pouch, right, lateral view. G. Dendrocephalus lithacus, male, labrum, ventral view. H. Dendrocephalus lithacus, gonopods, right, lateral view. Scale bar: $\mathrm{A}-\mathrm{C}=1 \mathrm{~mm} ; \mathrm{D}-\mathrm{F}, \mathrm{H}=4 \mathrm{~mm} ; \mathrm{G}=0.25 \mathrm{~mm}$. 
Dendrocephalus (Dendrocephalinus) alachua (Dexter, 1953)

Fig. 1B, E

Branchinella alachua Dexter, 1953: 761, figs 24-28.

Branchinella alachua - Moore 1967: 219-220. — Belk \& Sissom, 1992: 314. — Belk \& Brtek 1995: 323. — Brendonck 1997: 451-454. — Brtek 1997: 21. — Brtek 2002: 54.

Dendrocephalus alachua - Rogers 2006: 7, 12.

\section{Material examined}

Holotype

USA • ^]; Florida, Alachua County; 6 Jul. 1947; R.W. Dexter leg.; USNM 93538.

Paratypes

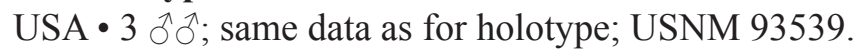

\section{Other material}

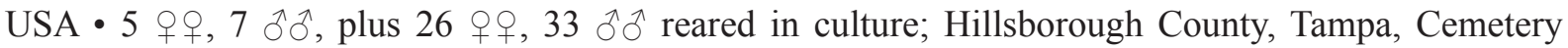
Pond, corner of Martin Luther King Boulevard and East Lake Avenue; $27^{\circ} 58.859^{\prime}$ N, 82 $2^{\circ} 24.256^{\prime}$ W; 13 Sep. 2000; substrate collected for culture 6 Jul. 2000; W.W. Price leg.; DCR \#772 • 41 우, 6 ठ David E. West Park, 2212 East $97^{\text {th }}$ Street, corner of Martin Luther King Boulevard and East Lake Avenue; $28^{\circ} 02.270^{\prime}$ N, $82^{\circ} 26.063^{\prime}$ W; 8 Jan. 2008; W.W. Price leg.; DCR \#774.

\section{Remarks}

The original description of the female has the brood pouch elongate, almost fusiform. In many, but not all, female specimens I have cultured, the brood pouch is abbreviated, lacking the free distal portion (Fig. 3E). This species is known from five unspecified collections in Alachua County, Florida, near Gainesville (Dexter 1953; Moore 1967; two unpublished records at USNM), and was suggested as possibly extinct, pending further surveys, even after many surveys were performed (Rogers, 2006). However, collecting efforts by W.W. Price yielded two new localities in the Tampa region. The Tampa locality is at least $180 \mathrm{~km}$ south of the unspecified type locality (a "barrow pit" (Dexter 1953) which has probably been destroyed (Rogers 2006)). For both new locations for this species the substrate has no measurable calcium carbonate and salinity 0 to $\sim 2 \mathrm{mS} / \mathrm{cm}$, as both locations are heavily vegetated, and have tree cover, with the substrate covered in vegetative debris (Rogers 2014b; this study). Similarly, both locations are less than a meter above the water table.

Dendrocephalus alachua co-occurred at both new locations with the smooth clam shrimp Lynceus gracilicornis Packard, 1871, and the spiny clam shrimp Eulimnadia cylindrova Belk, 1989. Both Dexter (1953) and Moore (1967) reported D. alachua co-occurring with the anostracan Streptocephalus sealii Ryder, 1879. However, this species was not present at either of the two new localities.

Rogers (2006) conservatively designated D. alachua as CR A1 species (IUCN 2000) pending further surveys. But with these new collections this species meets the IUCN red list CR B1a,b species criteria (IUCN 2000), that the species is 'Critically Endangered', with an extent of occupancy less than $100 \mathrm{~km}^{2}$, and a projected decline in extent of occurrence.

Dendrocephalus (Dendrocephalinus) lithacus (Creaser, 1940)

Fig. $1 \mathrm{C}, \mathrm{G}-\mathrm{H}$

Chirocephalus lithacus Creaser, 1940: 435, figs 1-6. 
Chirocephalus lithacus - Dexter 1953: 761.

Branchinella lithaca - Belk \& Sissom 1992: 314. - Belk \& Brtek 1995: 325. — Brendonck 1997: 451-454. - Brtek 1997: 22. — Brtek 2002: 54.

Dendrocephalus lithica - Rogers 2006: 7, 12.

\section{Material examined}

Holotype

USA - Feorgia, DeKalb County, Stone Mountain, within 100 yards of airway beacon; 9 Jun. 1939; USNM 79294.

\section{Allotype}

USA • + ; same data as for holotype; USNM 79295.

\section{Paratype}

USA • + ; same data as for holotype; USNM 79296.

\section{Remarks}

This species is known from a set of rock outcrop pools on Stone Mountain in Georgia and has only been collected twice (Dexter 1953). A petition was made to list D. lithacus as endangered under the United States Federal Endangered Species Act. However, after extensive survey efforts no evidence of extant populations of D. lithacus was found (Federal Register May 27, 1998) and the petition was denied (Rogers 2006). Surveys made by the Georgia Department of Natural Resources at Stone Mountain and other granitic plutons in the area have so far yielded no new populations. This species is most likely extinct. The clam shrimp Eulimnadia graniticola Rogers et al., 2010 occurs in these pools.

Dendrocephalus (Dendrocephalinus) proeliator sp. nov. urn:1sid:zoobank.org:act:203C0A81-A3CD-4A02-9001-47259EE2EA7C

Fig. 2

\section{Diagnosis}

Males are typical of the subgenus Dendrocephalinus, and readily identified in that the frontal appendage primary arms are each triramal, with branch $2 \mathrm{~A}$ bearing an apical hamulate projection. The antenna-like appendage is extremely small and may be obscured. Females are not separable.

\section{Etymology}

The specific epithet 'proeliator' is Latin for 'warrior'. The gender is masculine.

\section{Material examined}

Holotype

USA - ${ }^{\prime}$; Florida, Dade County; $25^{\circ} 34.781^{\prime} \mathrm{N}, 80^{\circ} 34.541^{\prime} \mathrm{W} ; 1.5 \mathrm{~m}$ a.s.l., on west side of SW $237^{\text {th }}$ Avenue, south of Grossman Hammock; 30 Jul. 2001; E.L. Nance leg.; FLMNH Type 49581.

\section{Allotype}

USA • + , same data as for holotype; FLMNH Type 49582.

\section{Paratypes}

USA $\bullet 4$ 우, 1 đ; same data as for holotype; FLMNH Type 9041. 


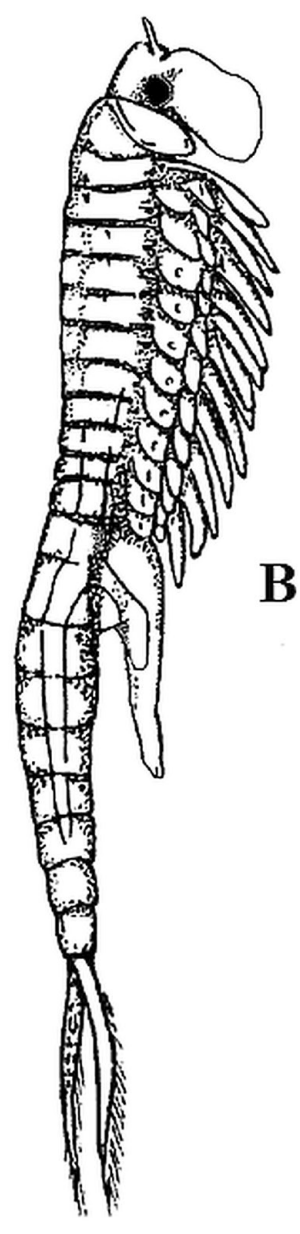

B

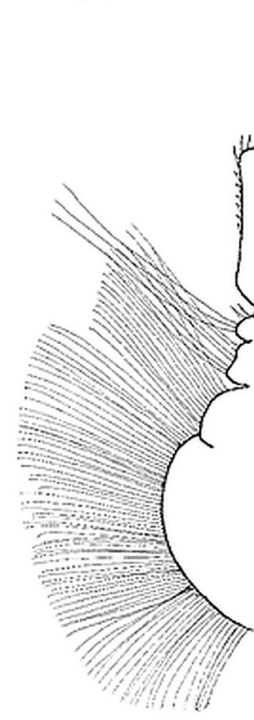

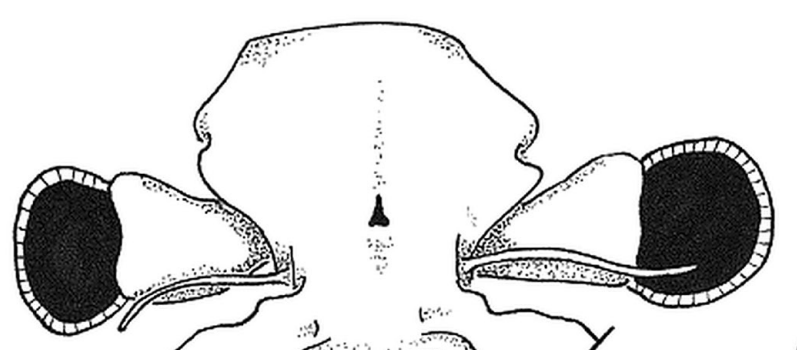

A

D

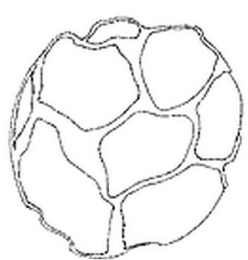

C

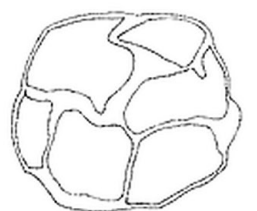

Fig. 2. Dendrocephalus proeliator sp. nov. Paratypes; Florida, Dade County; FLMNH Type 9041. A. Male head, anterior view. B. Female, right lateral view. C. Right limb V, anterior view. D. Two examples of the egg. Abbreviations: $1 \mathrm{~V}=$ first ventral branch; $2 \mathrm{~A}=$ apical branch; $2 \mathrm{D}=$ dorsal branch (terminology follows Pereira 1983). Scale bar: $A=2 \mathrm{~mm} ; \mathrm{B}=7 \mathrm{~mm} ; \mathrm{C}=1 \mathrm{~mm} ; \mathrm{D}=1.5 \mathrm{~mm}$. 


\section{Other material}

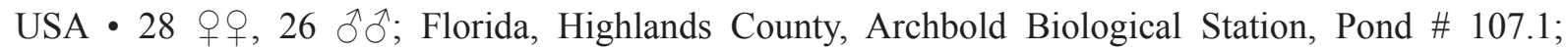

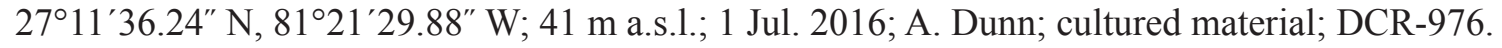

\section{Type locality}

The type locality is Pond \#107.1 at the Archbold Biological Station; a temporary pool in calcareous wet prairie. The substrate is Duette Sand, the pool fills to a maximum observed depth of $10 \mathrm{~cm}$, and the subcircular basin is approximately $15 \mathrm{~m}$ across. These soils are calcareous and have a salinity of $\sim 2 \mathrm{mS} /$ $\mathrm{cm}$. The basin substrate has $100 \%$ vegetative cover, dominated by approximately $70 \%$ yellow hatpin (Syngonanthus flavidus (Michx.) Ruhland, 1903) and 30\% Florida bluestem (Andropogon floridanus Scribn., 1896). A cluster of scrub oaks (possibly Quercus geminata Small, 1897) is in the center, providing shade and leaf litter. The surrounding area is scrubby flatwoods; a mixture of saw palmetto and shrubs with scattered pitch pine.

\section{Description}

\section{Male}

LENGTH. Average length of preserved material: $4.5 \mathrm{~mm}$ (males) and $8.2 \mathrm{~mm}$ (females) from apex of head to apex of telson.

HEAD (Fig. 2A). Male anteriolateral corner of head slightly projecting over eyestalk base. Labrum smooth. Antenna-like appendage anteriobasal to eyestalk, filiform, obscure, length approximately $0.1 \times$ eyestalk peduncle. First antenna approximately $85 \%$ the length of eye plus eyestalk. Second antenna capable of extending to thoracomere II or III. Second antennal proximal antennomere subcylindrical, smooth, with length approximately $3.0 \times$ distoapical width. Proximal antennomere distal end with short, medial, lobiform projection. Projection protruding slightly distally, smooth, apically rounded, length approximately $0.1 \times$ antennomere. Second antennal distal antennomere length slightly longer than proximal antennomere, flattened anterioposteriorly, gently arcuate medially, with apex acute and directed medially. Medial edge distal $\sim 55 \%$ margined with fine, aciculate denticles, directed subdistally. Cephalic appendage prominent, typical of the subgenus. Proximal trunk subcylindrical, smooth, lacking spines. Primary branches smooth, lacking spines, diverging approximately even with the distal end of the second antenna proximal antennomere. Primary branch triramal. Distal branches diverging at distal end of primary branch. Primary branch length $\sim 3.4 \times$ proximal trunk. Branch $2 \mathrm{~V}$ thick, flattened, with numerous semiannulations. Length $\sim 0.7 \times$ primary branch. Apex tapering in distal third. Distal fourth with four lateral lobes on each margin. Lobes and apex tipped with an acute spine. Spine length $\sim 2.5 \times$ basal width. Branch 2D flagelliform, subequal in length to primary branch, lacking spines or setae. Branch $2 \mathrm{~A}$ roughly triangular, with a chitinised tumid area covering approximately one third of the lateral surface, bearing rows of large chitinised, spiniform projections. Spiniform projections smaller distally and medially, length ranging from $\sim 0.5 \times$ to $1.0 \times$ basal width. Spiniform projections posteriorly and laterally becoming larger, subcylindrical, length ranging from $\sim 1.0 \times$ to $2.0 \times$ basal width, each bearing an apical ring of spinulae. Spinulae number three to five per projection. Branch $2 \mathrm{~A}$ distally chitinised, hamulate, with apex subacute. Distal hamulate projection chitinised, length $\sim 0.25$ total branch 2A length. Maxillae lobiform and transverse, no setae visible.

Thoracopods (Fig. 2C). Serially homologous. Thoracopod V with endites margined with long, plumose setae. Endite VI with two distal spines. Endopod subquadrate, with distal margin bearing a submedial emargination. Endopod with distomedial margin bearing a row of acute spines, length $\sim 3 \times$ basal width, separated by their basal width. Endopod distal margin mesad of emargination with four spines, slightly curved posteriorly, length $\sim 4 \times$ basal width, separated by their basal width. Endopod distal margin lateral of emargination bearing a row of cirriform setae, length $\sim 5.0 \times$ to $6.0 \times$ the distal spines. Endopod of all thoracopods, except thoracopod I lack setae on basomedial margin. Thoracopod I and II endopods 
as in other limbs, although the basomedial margin bears a few obscure filiform setae. Exopod lamellar, sinuate, margined in distal half with long, plumose, recurved setae. Epipodite elliptic and without marginal setae. Margins crenulate. Praepipodite broadly triangular, lamellar, without marginal setae, bearing a light mediolateral cleft.

Genitalia. Genital segments smooth. Retracted gonopod as for genus. Everted gonopods not observed. Abdomen smooth, cercopods $2 / 3$ as long as abdomen, margined with plumose setae.

\section{Female}

Generally as typical for the genus (Fig. 2B).

HEAD. Rounded, anterolateral corners slightly projecting over eyestalk base. First antenna length $0.25 \times$ second antenna. Second antenna broadly elliptic, lamellar. Thorax smooth. Thoracopods as in male, except endopods lacking emargination.

BRoOD POUCH. Fusiform, extending to proximal margin of postgenital abdominal segment IV.

\section{Eggs}

Subspherical, diameter approximately $190 \mu \mathrm{m}$, with large, broad pentagonal or quadragonal facies, each face diameter approximately $60 \mu \mathrm{m}$ (Fig. 2D).

\section{Differential diagnosis}

Of the four species of Dendrocephalus (Dendrocephalinus), males of D. proeliator sp. nov. are morphologically intermediate between D. lithacus (Fig. 1C) and D. alachua (Fig. 1B). These three species are easily differentiated from $D$. acacioidea (Fig. 1A) which lacks branch $2 \mathrm{~A}$ in the frontal appendage. The three remaining species bear the lateral, broad surface of branch $2 \mathrm{~A}$ with its rows of spiniform projections. Dendrocephalus proeliator sp. nov. bears three rami, as does D. alachua, and the three rami are superficially similar in overall structure between the two taxa. However, the hamulate distal projection of $D$. proeliator sp. nov. is absent in D. alachua. This hamulate distal projection is present in D. lithacus.

Dendrocephalus proeliator sp. nov. is further separated from $D$. alachua in that branch $2 \mathrm{~V}$ has eight total lateral lobes verses nine in D. alachua, and branch 2D is long, flagelliform and smooth in $D$. proeliator sp. nov. instead of vermiform and bearing rings of spines in D. alachua. Furthermore, branch 2D is proportionately much longer in $D$. proeliator $\mathrm{sp}$. nov. than in $D$. alachua. Dendrocephalus alachua also has a distomedial spiniform projection at the apex of the second antennal distal antennomere, which is lacking in D. proeliator sp. nov.

Dendrocephalus lithacus lacks the branch $2 \mathrm{D}$ found in the other two species, and branch $2 \mathrm{~A}$ is proportionately larger and more robust than the condition found in $D$. proeliator $\mathrm{sp}$. nov. The hamulate projection of branch $2 \mathrm{~A}$ in $D$. proeliator sp. nov. is approximately one fourth the total length of the branch, whereas in D. lithacus it is nearly half the branch length. Dendrocephalus lithacus also bears a row of fine spinulae on the second antenna proximal antennomere just basal to the frontal appendage, and a second row on the posteriolateral margin of the frontal appendage main trunk. These are lacking in $D$. proeliator sp. nov. and D. alachua. The second antennae distal antennomere medial margin bears spaced transverse grooves in D. lithacus versus a row of fine denticles in D. proeliator sp. nov. 


\section{Distribution and habitat}

So far, this species is only known from two locations in southern peninsular Florida. Both sites are temporary pools in calcareous wet prairie. Both sites are in sandy loam soils, with $50-90 \%$ calcium carbonate, and salinity around $2.0 \mathrm{mS} / \mathrm{cm}$.

The pool south of Grossman Hammock is inside Everglades National Park, in an area of state managed lands in Water Conservation Area 3B (Kambly \& Moorehead 2009). The type locality resides within the land managed by the Archbold Biological Station, established in 1941 by Archibold Expeditions, a non-profit, independent research organisation, based in Florida.

Due to the limited distribution of $D$. proeliator sp. nov., this species meets the IUCN red list CR B1a,b species criteria (IUCN 2000), which means the species is 'Critically Endangered', with an extent of occupancy less than $100 \mathrm{~km}^{2}$, and a projected decline in extent of occurrence. It is our hope that future surveys will find additional populations.

\section{Behaviour}

Mate searching behaviour was described in detail by Rogers (2019). Anostracans engage in hill topping behaviour, wherein salient objects are used as congregation points for males and receptive females. We observed this same hill topping behaviour in D. alachua and D. proeliator sp. nov. However, both species engaged in male-male agonistic interactions, wherein males actively attempt to drive each other away from hill topping points.

Males would patrol salient objects as described by Rogers (2019). When another male was encountered (Fig. 3A), they would attempt to inspect each other as potential mates (sensu Rogers 2019), but in attempting to inspect, each would not let the other beneath them, and they would circle, always facing each other (Fig. 3B). This would lead to instances of butting heads and actively feeling each other with the first antennae (Fig. 3C), interspersed with more circling. Occasionally, one would be able to get past its opponent's head and push them on the side (Fig. 3D). Typically, if a male had eyes closer set, or was pushed once or twice on the side, it would flee the other male (Fig. 3E-F). Presumably, the male with the wider set eyes would be larger and so the smaller one would flee to find a new hill topping site.

The activity of the first antennae during these encounters may be entirely tactile, or there may be some sort of chemosensory occurring as is observed in agonistic behaviour in crayfish (Bergman \& Moore 2005).

\section{Key to the species of Dendrocephalinus}

1. Male frontal appendage with each main branch bearing two sub-branches

- Male frontal appendage with each main branch bearing three sub-branches

2. Frontal appendage with sub-branch $1 \mathrm{~V}$, lamellar, margined with spiniform papillae; sub-branch $2 \mathrm{D}$ absent; sub-branch 2A broad, with chitisied papillae on lateral surface, terminating in a chitinised, hamulate spine (Fig. 1C)

Dendrocephalus lithacus (Creaser, 1940) (USA: Georgia, possibly extinct)

- Frontal appendage with sub-branch 1V and 2D lamellar, margined with spiniform papillae; subbranch 2A absent (Fig. 1A) .....Dendrocephalus acacioidea (Belk \& Sissom, 1992) (USA: Texas)

3. Frontal appendage with sub-branch 2D lacking spines or papillae; sub-branch $2 \mathrm{~A}$ terminating in a chitinised, hamulate spine (Fig. 2A) Dendrocephalus proeliator sp. nov. (USA: Florida) 


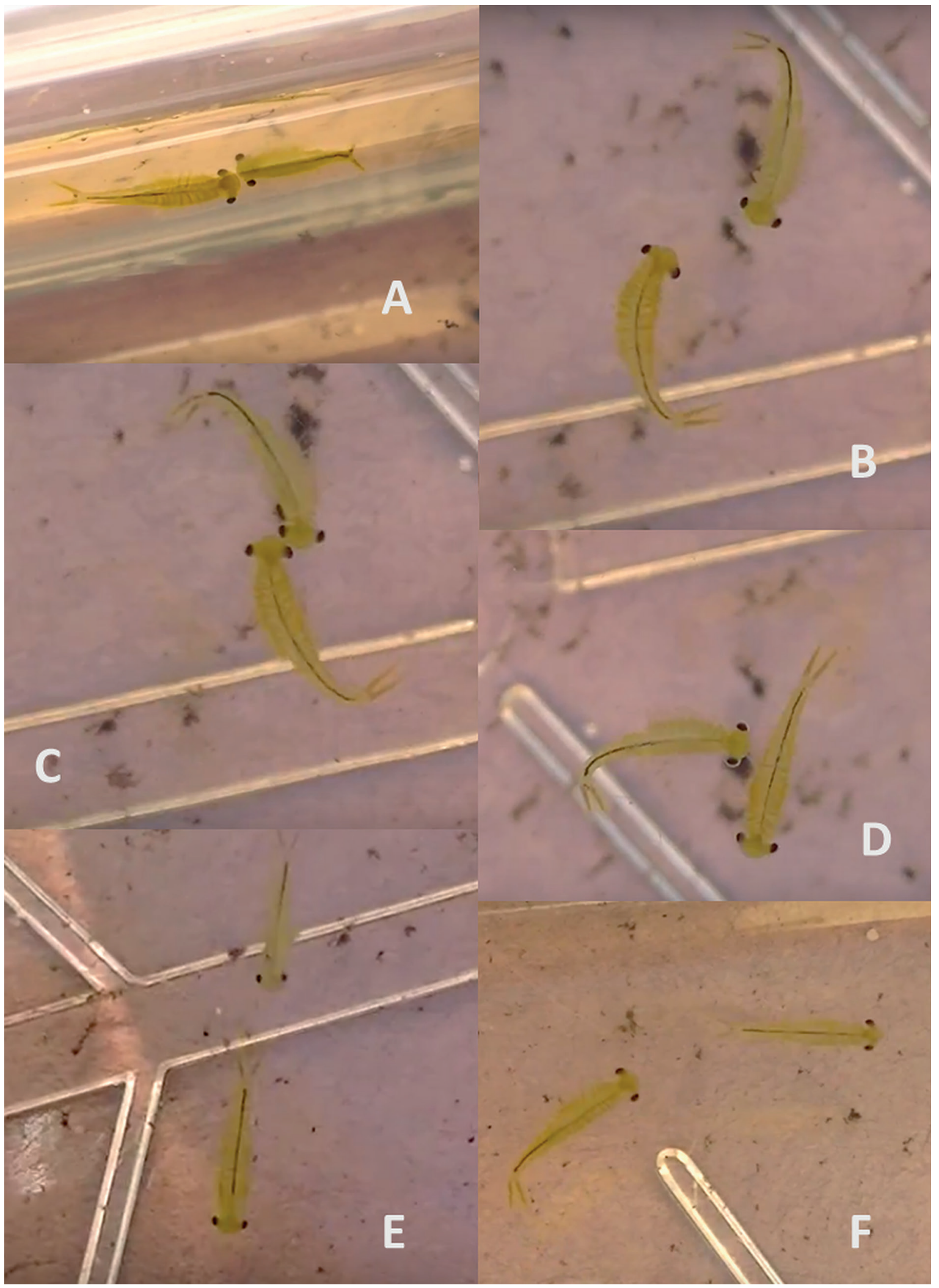

Fig. 3. Dendrocephalus proeliator sp. nov, male-male aggressive interactions. A. Encounter. B. Circling. C. Head to head attack. D. Broadside attack. E-F. Chasing. 
- Frontal appendage with sub-branch 2D with small scattered spines; sub-branch 2A lacking a chitinised, hamulate spine (Fig. 1B) ......... Dendrocephalus alachua (Dexter, 1953) (USA: Florida)

\section{Discussion}

The subgenus Dendrocephalinus was suggested to have split from Dendrocephalus sometime in the late Paleozoic (around 270 million years ago) when South America and North America were together at the equator, or at some point Dendrocephalinus was the result of founder Dendrocephalus populations invading North America (Rogers 2006). The fact that D. acacioidea is quite different in terms of frontal appendage morphology and is disjunct from the other three species, suggests that it may be basal to the other species. The strong similarity of gonopodal morphology leaves little doubt that it belongs in Dendrocephalinus.

Dendrocephalinus is smaller, more gracile, and the frontal appendage is greatly reduced and less elaborate than in Dendrocephalus s. str. Sexually mature adult preserved Dendrocephalus s. str. material in DCR's collection range from 10 to $16 \mathrm{~mm}$ total body length (from anterior margin of the head to posterior margin of the telson), whereas in Dendrocephalinus the range is from 4 to $9 \mathrm{~mm}$.

The frontal appendage of Dendrocephalus s. str. has two ventral branches (1V, which is biramal, and $2 \mathrm{~V})$, a bi- or triramal dorsal branch (2D), and an apical branch that bears some form of a chitinised hook (2A). In Dendrocephalinus only the single ventral branch remains (1V), and it is of a single ramus that strongly resembles the $1 \mathrm{~V}$ anterior sub-branch of Dendrocephalus s. str. The $2 \mathrm{D}$ branch, if present, is only one ramus, which either resembles $1 \mathrm{~V}$ or is flagellar. The $2 \mathrm{~A}$, if present, is broad, and covered with chitinised papillae, and may or may not have the apical hook.

The elaborate male-male aggressive behaviour over hill topping sites is competition for access to receptive females. Anostracans live in seasonally astatic aquatic habitats with highly stochastic hydroperiods. This would suggest that aggressive interactions would be time ill spent; the limited hydroperiod would necessitate that the animals focus on reproduction. However, these species live in the Coastal Plain Anostracan Bioregion (Rogers 2014a), which frequently has long periods of precipitation, particularly in the summer months, from tropical storms and hurricanes. Thus, it is likely that these pools have prolonged hydroperiods providing time to engage in more competitive actions.

With the discovery of a new species in the subgenus, the existing key (Rogers \& Hann 2016) is no longer useful. Thus, we provide an updated key to the subgenus here.

\section{Acknowledgments}

The authors are especially grateful to Trisha Spears (Florida State University, Tallahassee), John Jensen, Thomas Floyd, and Colleen Cunningham (The Georgia Natural Heritage Program) for their help collecting in Florida and Georgia. We are also grateful for the generous and kind reviews provided by Luc Brendonck and an anonymous reviewer.

\section{References}

Belk D. \& Brtek J. 1995. Checklist of the Anostraca. Hydrobiologia 298: 315-353. https://doi.org/10.1007/bf00033826

Belk D. \& Sissom S.L. 1992. New Branchinella (Anostraca) from Texas, U.S.A., and the problem of antennalike processes. Journal of Crustacean Biology 12: 312-316. https://doi.org/10.2307/1549083

Belk D., Shug Belk M. \& Reading K.A.L. 2002. Survey of large branchiopods on Aruba and observations on taxonomic characters in Leptestheria (Spinicaudata). Hydrobiologia 486: 115-118. 
https://doi.org/10.1023/a:1021386315348

Bergman D.A. \& Moore P.A. 2005. The role of chemical signals in the social behavior of crayfish. Chemical Senses 30 (supplement 1): 305-306. https://doi.org/10.1093/chemse/bjh236

Brendonck L. 1997. The anostracan genus Branchinella (Crustacea: Branchiopoda), in need of a taxonomic revision; evidence from penile morphology. Zoological Journal of the Linnaean Society 119: 447-455. https://doi.org/10.1111/j.1096-3642.1997.tb00142.x

Brendonck L., Thiery A. \& Coomans A. 1990. Taxonomy and biogeography of the Galapagos branchiopod fauna (Anostraca, Notostraca, Spinicaudata). Journal of Crustacean Biology 10: 676-694.

Brtek J. 2002. Taxonomical survey of the Anostraca, Notostraca, Cyclestherida, Spinicaudata, and Laevicaudata. Zborník Slovenského Národného Múzea / Prírodné vedy 48: 49-60.

Brtek J. \& Mura G. 2000. Revised key to families and genera of the Anostraca with notes on their geographical distribution. Crustaceana 73: 1037-1088.

Creaser E.P. 1940. A new species of phyllopod crustacean from Stone Mountain, Georgia. Journal of the Washington Academy of Sciences 30: 435-437.

Dexter R.W. 1953. Studies on North American fairy shrimps with the descriptions of two new species. American Midland Naturalist 49: 751-771. https://doi.org/10.2307/2485207

IUCN 2001. IUCN Red List Categories and Criteria: Version 3.1. IUCN Species Survival Commission. IUCN, Gland/Switzerland/Cambridge, UK.

Kambly S. \& Moreland T.R. 2009. Land cover trends in the Southern Florida Coastal Plain. U.S. Geological Survey Scientific Investigations Report 5054: 1-16.

Moore W.G. 1967. The female of Branchinella alachua Dexter (Branchiopoda, Anostraca). Transactions of the American Microscopial Society 86: 219-220. https://doi.org/10.2307/3224696

Pereira G. 1983. Taxonomic importance of the frontal appendage in the genus Dendrocephalus (Anostraca: Thamnocephalidae). Journal of Crustacean Biology 3: 293-305.

https://doi.org/10.2307/1548264

Rabet N., Lacau S., \& Bozelli R.L. 2018. Richness of Dendrocephalus (Branchiopoda, Anostraca) in Brazil with the description of two new species. European Journal of Taxonomy 478: 1-20.

https://doi.org/10.5852/ejt.2018.478

Rogers D.C. 2006. Revision of the thamnocephalid Genus Phallocryptus (Crustacea; Branchiopoda; Anostraca).. Zootaxa 1260: 1-25. https://doi.org/10.11646/zootaxa.257.1.1

Rogers D.C. 2013. Anostraca Catalogus. The Raffles Bulletin of Zoology 61: 525-546.

Rogers D.C. 2014a. Anostracan (Crustacea: Branchiopoda) zoogeography I. North American bioregions. Zootaxa 3838: 251-275. https://doi.org/10.11646/zootaxa.3838.3.1

Rogers D.C. 2014b. Anostracan (Crustacea: Branchiopoda) zoogeography II. Relating distribution to geochemical substrate properties in the USA. Zootaxa 3856: 1-49.

https://doi.org/10.11646/zootaxa.3856.1.1

Rogers D.C. 2019. Mate searching behaviour and sex pheromones in the Anostraca (Branchiopoda). Journal of Crustacean Biology. https://doi.org/10.1093/jcbiol/ruy099

Rogers D.C. \& Hann B.J. 2016. Class Branchiopoda. In: Thorp J.H. \& Rogers D.C. (eds) Thorp \& Covich's Freshwater Invertebrates, $4^{\text {th }}$ edition, Volume II: Keys to the Nearctic Fauna: 437-477. Academic Press. London. 
Rogers D.C. \& Volcan M.V. 2016. A new Dendrocephalus (Crustacea, Anostraca, Thamnocephalidae) from Rio Grande do Sul State, Brazil. Nauplius 24: 1-9. https://doi.org/10.1590/2358-2936e2016014

Rogers D.C., Weeks S.C. \& Hoeh W.R. 2010. A new species of Eulimnadia (Crustacea; Branchiopoda; Diplostraca; Spinicaudata) from North America. Zootaxa 2413: 61-68.

Rogers D.C., Gomes J.P.C. \& Viera F. 2012. A new species of Dendrocephalus (Crustacea, Anostraca) from Serra dos Carajás (Pará State, Brasil). Zootaxa 3363: 52-58.

Rogers D.C., Cohen R.G. \& Hann B.J. In press. Class Branchiopoda. In: M.C. Damborena, D.C. Rogers, \& J.H. Thorp (eds). Thorp \& Covich's Freshwater Invertebrates, $4^{\text {th }}$ edition, Volume V: Keys to the Neotropical Fauna. Academic Press. London.

Manuscript received: 30 October 2018

Manuscript accepted: 31 January 2019

Published on: 26 March 2019

Topic editor: Rudy Jocqué

Desk editor: Eva-Maria Levermann

Printed versions of all papers are also deposited in the libraries of the institutes that are members of the EJT consortium: Muséum national d'Histoire naturelle, Paris, France; Meise Botanic Garden, Belgium; Royal Museum for Central Africa, Tervuren, Belgium; Royal Belgian Institute of Natural Sciences, Brussels, Belgium; Natural History Museum of Denmark, Copenhagen, Denmark; Naturalis Biodiversity Center, Leiden, the Netherlands; Museo Nacional de Ciencias Naturales-CSIC, Madrid, Spain; Real Jardín Botánico de Madrid CSIC, Spain; Zoological Research Museum Alexander Koenig, Bonn, Germany. 